\title{
High Sensitivity pH Sensor Based on Porous Silicon (PSi) Extended Gate Field-Effect Transistor
}

\author{
Naif H. Al-Hardan 1,*, Muhammad Azmi Abdul Hamid ${ }^{1, *}$, Naser M. Ahmed ${ }^{2}$, Azman Jalar ${ }^{3}$, \\ Roslinda Shamsudin ${ }^{1}$, Norinsan Kamil Othman ${ }^{1}$, Lim Kar Keng ${ }^{1}$, Weesiong Chiu ${ }^{4}$ \\ and Hamzah N. Al-Rawi ${ }^{5}$ \\ 1 School of Applied Physics, Faculty of Science and Technology, Universiti Kebangsaan Malaysia (UKM), \\ 43600 Bangi, Selangor, Malaysia; linda@ukm.edu.my (R.S.); insan@ukm.edu.my (N.K.O.); \\ karkeng.iamkklim@gmail.com (L.K.K.) \\ 2 School of Physics, Universiti Sains Malaysia (USM), 11800 Penang, Pulau Pinang, Malaysia; naser@usm.my \\ 3 Institute of Microengineering and Nanoelectronics (IMEN), Universiti Kebangsaan Malaysia (UKM), \\ 43600 Bangi, Selangor, Malaysia; azmn@ukm.edu.my \\ 4 Low Dimensional Materials Research Centre, Department of Physics, Faculty of Science, \\ University of Malaya, 50603 Kuala Lumpur, Malaysia; w.s.chiu@um.edu.my \\ 5 School of Electrical and Electronic Engineering-Universiti Sains Malaysia (USM), 14300 Nibong Tebal, \\ Pulau Pinang, Malaysia; comeon500@yahoo.com \\ * Correspondence: naif@ukm.edu.my (N.H.A.-H.); azmi@ukm.edu.my (M.A.A.H.); \\ Tel.: +60-3-989-217-002 (N.H.A.-H. \& M.A.A.H.)
}

Academic Editor: Ki-Hyun Kim

Received: 9 March 2016; Accepted: 25 May 2016; Published: 7 June 2016

\begin{abstract}
In this study, porous silicon (PSi) was prepared and tested as an extended gate field-effect transistor (EGFET) for $\mathrm{pH}$ sensing. The prepared PSi has pore sizes in the range of 500 to $750 \mathrm{~nm}$ with a depth of approximately $42 \mu \mathrm{m}$. The results of testing PSi for hydrogen ion sensing in different $\mathrm{pH}$ buffer solutions reveal that the PSi has a sensitivity value of $66 \mathrm{mV} / \mathrm{pH}$ that is considered a super Nernstian value. The sensor considers stability to be in the $\mathrm{pH}$ range of 2 to 12 . The hysteresis values of the prepared PSi sensor were approximately 8.2 and $10.5 \mathrm{mV}$ in the low and high $\mathrm{pH}$ loop, respectively. The result of this study reveals a promising application of PSi in the field for detecting hydrogen ions in different solutions.
\end{abstract}

Keywords: macroporous materials; ionic conductivity; $\mathrm{pH}$ sensitivity

\section{Introduction}

Porous silicon (PSi) is a promising candidate for several applications due to the ease of fabrication and controllable pore size. Furthermore, it is compatible with conventional silicon processing technology [1]. Moreover, PSi attracted the attention of several groups in the past years for several applications. The surface modification of the silicon wafer plays a major role in the sensitivity enhancement of silicon (Si) toward several analytes, and it was successfully deployed in the development of a large variety of biosensors [2-6]. Furthermore, several applications of PSi were investigated, such as light emitted diodes (LED) [7-9], photodetectors [10-12], waveguides [13], and chemical sensors for detection of various chemicals [5,14-17]. Furthermore, PSi exhibits a number of properties that make it an attractive material for controlled drug delivery applications [18]. The $\mathrm{H}^{+}$ ions $(\mathrm{pH})$ are crucial parameters in biomedical research. A few methods were conducted to measure the $\mathrm{pH}$ of the solutions; among them is the extended gate field-effect transistor (EGFET). With this method, a commercial metal-oxide-semiconductor field-effect transistor (MOSFET) is isolated from the chemical environment, and a chemical sensing membrane is located in the media and connected to the gate of the MOSFET. With this configuration, the MOSFET can be used many times without 
any damage as compared to the ion sensitive field-effect transistors (ISFETs), where the metallic gate of the MOSFET is replaced by a sensitive membrane [19-21]. It is worth noting that the theoretical framework of both platforms is essentially the same [22,23].

Several materials were tested as a sensing membrane, among them the metal oxide semiconductors such as zinc oxide [24,25], titanium dioxide [26], palladium oxide [23], and ruthenium dioxide [27]. However, some metal oxides demonstrate poor performance and need special treatments to be used as membranes for extreme $\mathrm{pH}$ values $[22,24,28,29]$. The cost effective preparation method, ease of fabrication of the PSi compared with the metal oxide semiconductors, and the rigid property of the silicon wafer (as a substrate) make it preferable in biosensing applications.

Porous silicon has previously been employed for $\mathrm{pH}$ sensing in different platforms. Zehfroosh et al. [21] prepared ISFET with PSi on the gate region. The calculated $\mathrm{pH}$ sensitivity was $300 \mathrm{mV} / \mathrm{pH}$ in the $\mathrm{pH}$ range of 4 to 9 . This value of the sensitivity was higher than the theoretical value of the Nernst limit $(59 \mathrm{mV} / \mathrm{pH})$. Furthermore, it was shown that increasing the drain current enhanced the sensitivity values. The PSi-based potentiometric method was employed for an enzymatic biosensor by Rebby et al. [30,31]. The PSi was tested under different $\mathrm{pH}$ environments. The sensitivity was calculated to be $30 \mathrm{mV} / \mathrm{pH}$ in the $\mathrm{pH}$ range of 4.6 to 8.09 . A capacitive $\mathrm{pH}$ sensor based on PSi was prepared by Schöning et al. [32]. The $\mathrm{pH}$ sensitivity was found to be $60 \mathrm{mV} / \mathrm{pH}$ in the range of $\mathrm{pH}=4$ to 9 with a hysteresis value of $3 \mathrm{mV}$.

The sensitivity of the sensing membrane depends on the change of the surface potential voltage $(\Psi)$ between the sensing layer and the electrolyte interface. This is based on the site binding theory [33]. In this theory, the number of binding sites residing on the sensing membrane could lead to changes in the surface potential voltage between the sensing layer and the electrolyte interface. This can be expressed as $[29,34,35]$ :

$$
\Psi=2.303 \frac{k T}{q} \frac{\beta}{\beta+1}\left(p H_{p z c}-p H\right)
$$

where $\mathrm{pH}_{\mathrm{pzc}}$ is the $\mathrm{pH}$ value at the point of zero charge, $q$ is the electron charge, $k$ is the Boltzmann constant, $T$ is the absolute temperature, and $\beta$ is the sensitivity parameter, which can be calculated using [36];

$$
\beta=\frac{2 q^{2} N_{s} \sqrt{\left(\frac{K_{a}}{K_{b}}\right)}}{k T C_{D L}}
$$

where $\mathrm{N}_{\mathrm{s}}$ represents the surface site density and $\mathrm{C}_{\mathrm{DL}}$ is the capacitance of the electrical double layer, as derived from the Gouy-Chapman-Stern model [35]. By increasing the sensitivity parameter $\beta$, a better linear response between the surface potential voltage and $\mathrm{pH}$ value can be obtained [36].

The theoretical limit value of the $\mathrm{pH}$ voltage sensitivity is known as the Nernst limit, and it is equal to $59 \mathrm{mV} / \mathrm{pH}[22,23,26]$. However, in order to solve this problem, several published works proposed different approaches to enhance the voltage sensitivity and cross the Nernst limitation. The enhancement of the voltage sensitivity was proposed via increasing the sensing gate surface area in the ISFET configuration, where a remarkable increase in the measured $\mathrm{pH}$ sensitivity was noticed, and it reached $130 \mathrm{mV} / \mathrm{pH}$ [37]. The porous nature of the sensing membrane proves to be another approach in enhancing the $\mathrm{pH}$ sensitivity. The porous structure of the membrane will increase the accumulation of positive charges on the gate region. The $\mathrm{pH}$ sensitivity achieved a value of $300 \mathrm{mV} / \mathrm{pH}$ for ISFET platform [21]. Furthermore, a dual-gate ISFET platform was proposed by Spijkman et al. [38]. The $\mathrm{pH}$ voltage sensitivity was reported to be $2.25 \mathrm{~V} / \mathrm{pH}$. With this type of configuration, a capacitive coupling effect is induced between the top and bottom gate capacitance that will result in the enhancement in $\mathrm{pH}$ sensitivity [34,38].

According to Yao et al. [22], the variation of the surface charge density with interfacial potential for the membrane surface is probably the reason for the departure from the Nernst equation. The porous nature of the membrane surface will increase the charge accumulation and play a major role in enhancing the capability of the membrane in sensing the hydrogen ions. 
In this report, we investigate PSi as a membrane for the EGFET pH measurement applications. To the best of our knowledge, the PSi pH sensor as an EGFET platform has not been previously investigated. The performance in the sensitivity and stability of PSi in different buffer solutions of $\mathrm{pH}$ will be explored.

\section{Materials and Methods}

\subsection{The Porous Silicon Formation}

The PSi layer was prepared via anodizing an n-type silicon (Si) wafer with orientation (100) and resistivity of $0.75-1.25 \Omega \cdot \mathrm{cm}$. The Si wafer was cleaned according to the standard procedure following the RCA method. The wafer was then cut into four pieces and inserted as an anode in the electrochemical etching cell. The polished side was facing the cathode (platinum wire with a diameter of $0.25 \mathrm{~mm}$ ). The DC photo-electrochemical etching bath was conducted at room temperature in a Teflon ${ }^{\circledR}$ cell containing a mixture of hydrofluoric acid ( $\left.\mathrm{HF} 48 \%\right)$ and ethanol $\left(\mathrm{C}_{2} \mathrm{H}_{5} \mathrm{OH} 98 \%\right)$ with a volume ratio of 1:4. The PSi layer was formed with a DC constant current at a current density of $20 \mathrm{~mA} / \mathrm{cm}^{2}$ for $15 \mathrm{~min}$ under illumination from a $100 \mathrm{~W}$ tungsten lamp; the lamp was fixed at a distance of $20 \mathrm{~cm}$. The samples were then rinsed with deionized water and dried with nitrogen gas. Figure 1 shows a schematic diagram of the anodization system used for the formation of PSi [39].

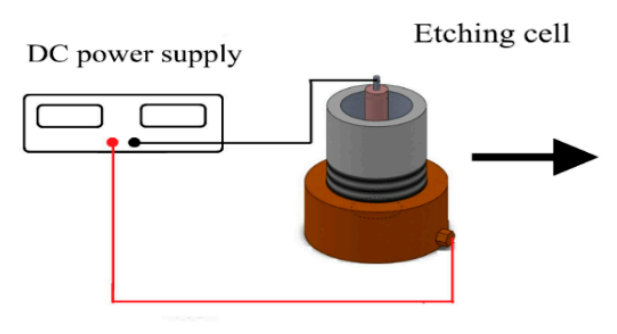

( a )

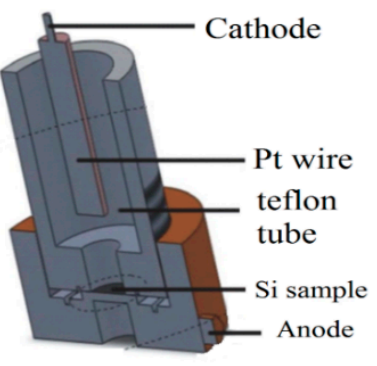

( b )

Figure 1. Experimental setup for PSi (a) and cross section of the etching cell (b).

\subsection{The Sensor Chip Fabrication}

Samples of $1 \mathrm{~cm} \times 1 \mathrm{~cm}$ in size were scribed from the Si wafer with PSi. The samples were mounted to a strip of a copper clad laminate printed circuit board (PCB) [23]. Conductive wire was connected between the Si wafer and the copper plate using silver paste. Epoxy resin was employed to encapsulate the sensor chip and the copper line of the clad sheet PCB to reduce the leakage current. An area of $0.3 \mathrm{~cm} \times 0.3 \mathrm{~cm}$ was free from epoxy and was used as a sensing window. Figure 2 presents the PSi membrane after encapsulation.

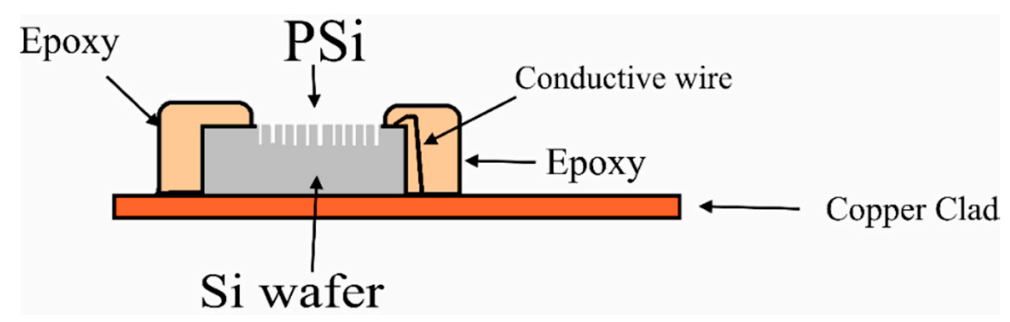

Figure 2. The fabricated PSi sensor on a copper-clad sheet. 


\subsection{Measurement Processes}

Two Keithley 2400 source measure units (SMUs) (Keithley Instruments, Inc., Cleveland, OH, USA) were used to analyze the membrane. The units were connected to a personal computer (PC) via a GPIB-USB cable, and LabTracer software (Keithley Instruments, Inc., Cleveland, OH, USA) was used to initiate the measurements and save the data for further analysis. The measurement system in this study is shown in Figure 3a. The electrode containing PSi was connected to the gate terminal of a commercial MOSFET (CD4007UB-Texas Instruments) and dipped into a buffer solution. To provide a stable reference voltage to the sensing element, a commercial $\mathrm{Ag}$ - $\mathrm{AgCl}$ reference electrode was dipped into the same buffer solution and kept at room temperature $\left(25^{\circ} \mathrm{C} \pm 1^{\circ} \mathrm{C}\right)$ for two mins before the measurements. One of the 2400 SMUs was used to apply the drain-source voltage ( $\mathrm{V}_{\mathrm{DS}}$ ) to the source and drain the terminals of the CD4007UB device and measure the drain-source output current $\left(\mathrm{I}_{\mathrm{DS}}\right)$, whereby the second $2400 \mathrm{SMU}$ was used to apply the reference voltage $\left(\mathrm{V}_{\mathrm{REF}}\right)$ to the reference electrode. The distance between the reference electrode and the PSi sensing electrode was fixed at $1.7 \mathrm{~cm}$.
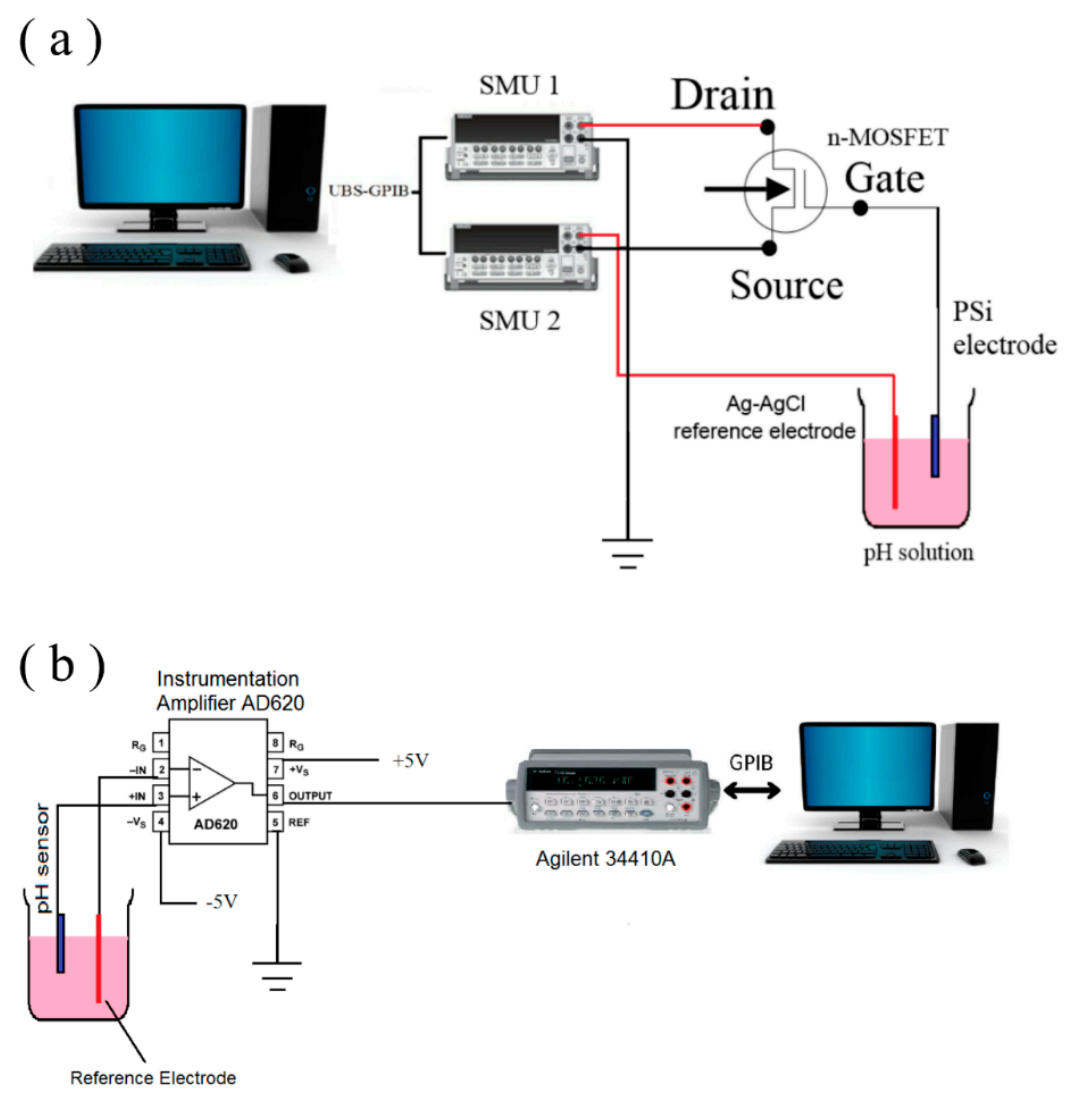

Figure 3. The pH-EGFET measurement setup. The measurement configuration of (a) I-V characteristics and (b) the hysteresis effect.

The hysteresis effect of the prepared PSi sensing membrane was measured using an instrumentation amplifier AD620 [40]. Figure 3b depicts the schematic of the measurement configuration for the hysteresis effect. The membrane was connected to Terminal 3 of the device, whereas the reference electrode was connected to Terminal 2. The operating voltage at Terminals 4 and 7 was $+5 \mathrm{~V}$ and $-5 \mathrm{~V}$, respectively. The sensor was kept for 12 hours in a buffer solution of $\mathrm{pH} 7$ so the membrane surface stabilized prior to the measurement. The multimeter Agilent 34410A was used to readout the data, and it was connected to the output terminal (Terminal 6) of the AD620. In addition, the Agilent 34410A was connected to a PC through a USB interface, and the data were stored in the PC. For this test, we immersed the membrane in alternating cycles of $\mathrm{pH}$ buffer solutions starting from 
$\mathrm{pH} 7 \rightarrow \mathrm{pH} 4 \rightarrow \mathrm{pH} 7 \rightarrow \mathrm{pH} 10 \rightarrow \mathrm{pH} 7$ for $60 \mathrm{~s}$ for each $\mathrm{pH}$ buffer solution. The standard phosphate buffer solutions with ( $\mathrm{pH}=2$ to 12 ) were purchased from HANNA instruments. All the measurements were conducted in a black box, and the temperature was controlled at $25^{\circ} \mathrm{C} \pm 1{ }^{\circ} \mathrm{C}$.

The surface morphologies of the prepared PSi were investigated using field-emission scanning electron microscopy (FE-SEM), which was conducted on a LEO SUPRA 55VP (Carl Zeiss) using energy-dispersive X-ray spectroscopy (EDX; Oxford Inca) to determine the elemental compositions.

\section{Results and Discussion}

\subsection{The PSi Surface Morphology}

The surface morphology of the prepared PSi at the current density of $20 \mathrm{~mA} / \mathrm{cm}^{2}$ for $15 \mathrm{mins}$ under illumination of $100 \mathrm{~W}$ is depicted in Figure 4.
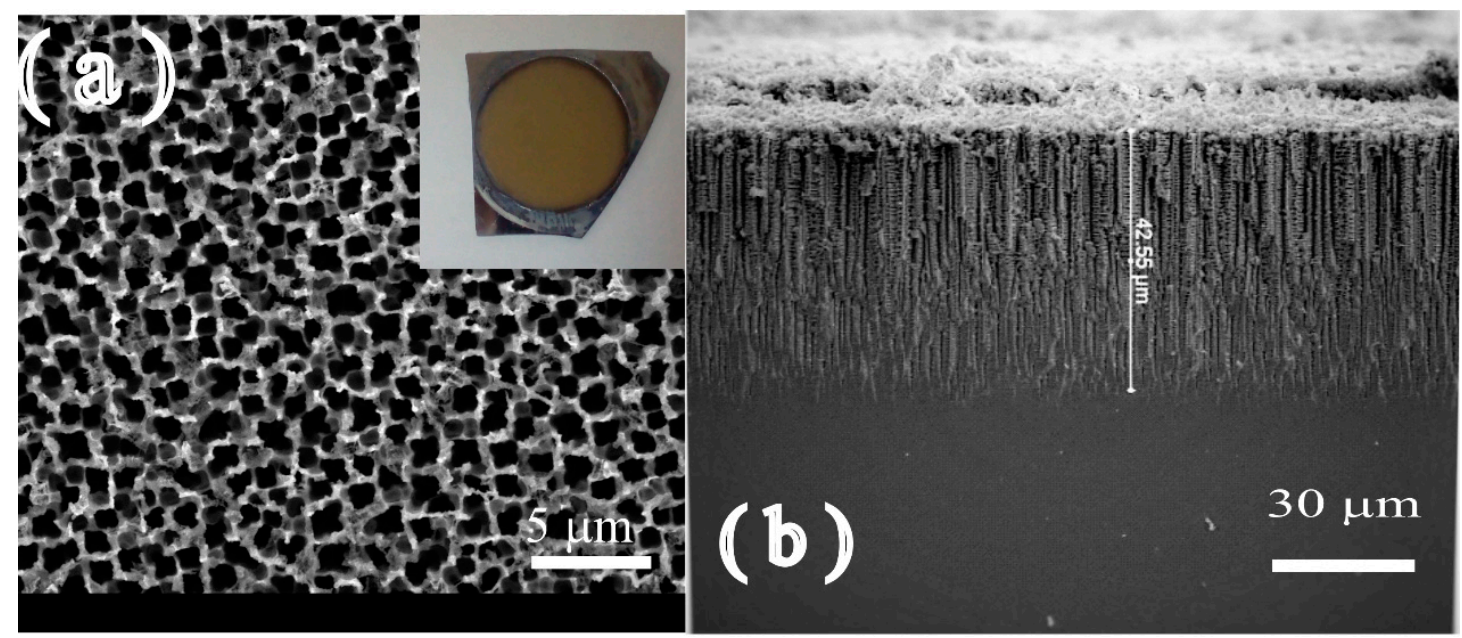

Figure 4. FE-SEM image of the surface: (a) inset depicts the optical image of the PSi surface and (b) cross section of the prepared PSi.

The FE-SEM image of the top view of the prepared PSi sample can be seen in Figure 4a, and it is clear that the pores are homogenous in their distribution. An average pore size of $500 \mathrm{~nm}$ to $750 \mathrm{~nm}$ was observed in the prepared sample. The optical image (inset in Figure 4a) illustrates the homogeneous surface of the prepared PSi sample. The figure also depicts a part of the cross section of the prepared PSi with a depth of approximately $42 \mu \mathrm{m}$ (Figure $4 \mathrm{~b}$ ).

The EDX scan of the surface shows the presence of three elements: carbon, oxygen, and silicon. The carbon probably originated from the etching process. The oxygen is probably in the form of $\mathrm{SiO}_{\mathrm{x}}$ and originated from the replacement of the $\mathrm{Si} / \mathrm{H}$ terminal bonds to more stable $\mathrm{Si} / \mathrm{O}$ bonds and can be presented as [14]:

$$
\mathrm{SiH}_{4}+2 \mathrm{H}_{2} \mathrm{O} \rightarrow \mathrm{SiO}_{2}+4 \mathrm{H}_{2}
$$

\subsection{The PSi Performance as a $\mathrm{pH}$ Sensor}

The EGFET turn-on voltage (threshold voltage; $\mathrm{V}_{\mathrm{T}}$ ) varies with the surface potential between the sensing film and the solution. The $\mathrm{V}_{\mathrm{T}}$ can be expressed as [22,23]:

$$
V_{T(E G F E T)}=V_{T(\text { MOSFET })}-\frac{\Phi_{M}}{q}+\mathrm{E}_{R E F}+\chi^{S o l}-\phi
$$

where $\mathrm{V}_{\mathrm{T}(\mathrm{MOSFET})}$ is the threshold voltage of the MOSFET, $\frac{\Phi_{M}}{q}$ is the metal gate work function, $\mathrm{E}_{\mathrm{REF}}$ is the potential of the reference electrode, $\chi^{S o l}$ is the surface dipole potential of the buffer solution, and $\phi$ is the surface potential at the electrolyte/sensing film interface. 
The relationship between $\mathrm{I}_{\mathrm{DS}}$ and $\mathrm{V}_{\mathrm{REF}}$ in the linear region of the EGFET can be expressed as [22,23];

$$
\mathrm{I}_{D S}=\mathrm{K}_{n}\left[2\left(\mathrm{~V}_{R E F}-\mathrm{V}_{T}\right) \mathrm{V}_{D S}-\mathrm{V}_{D S}^{2}\right]
$$

where $K_{n}$ is the conduction parameter [22].

The results of $I_{D S}$ and $V_{R E F}$ are depicted in Figure 5. The $V_{D S}$ was kept constant at $300 \mathrm{mV}$ (the linear region of the MOSFET).

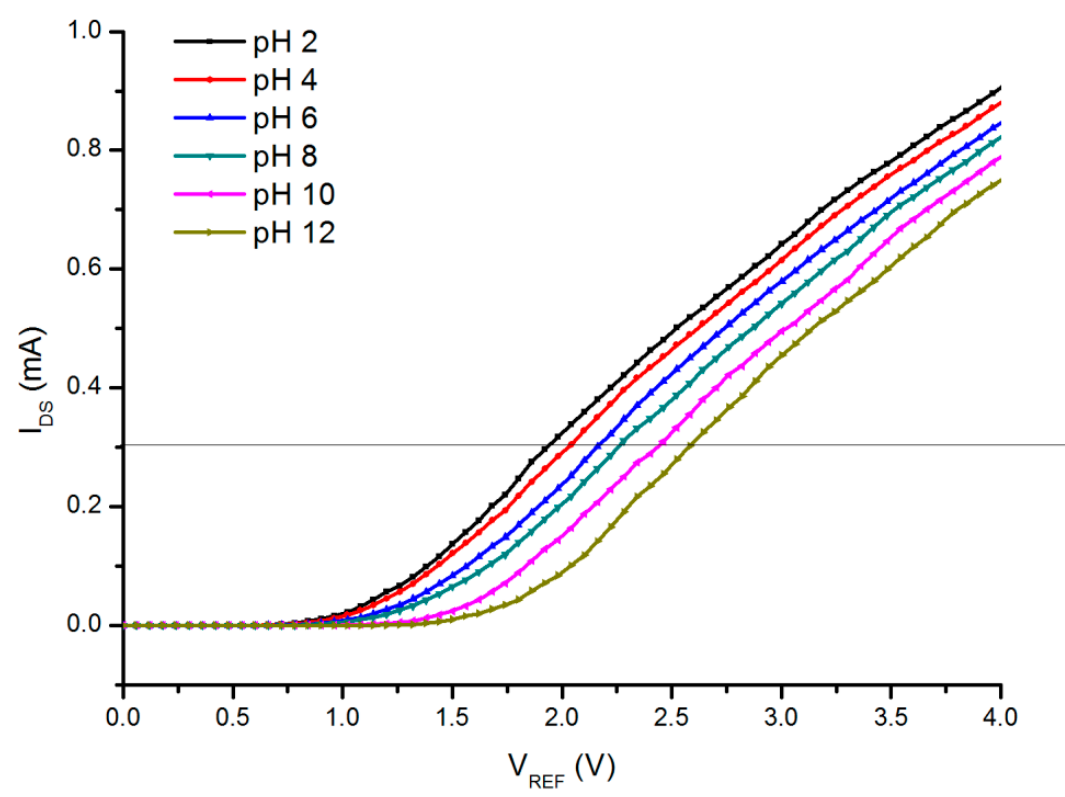

Figure 5. The $I_{D S}-V_{R E F}$ for the prepared PSi EGFET in the linear region for different $\mathrm{pH}$ buffer solutions ( $\mathrm{pH}=2$ to 12 ). The $V_{D S}$ was kept constant at $300 \mathrm{mV}$.

As seen in the figure, as the $\mathrm{pH}$ value increases (the $\mathrm{H}^{+}$ion content decreases), the $\mathrm{V}_{\mathrm{T}}$ of the EGFET is shifted to higher values (shifted from the left toward the right). From the graph, the pH voltage sensitivity and linearity can be calculated using the below formula:

$$
p H \text { voltage senstivity }=\frac{\Delta V_{T}}{\Delta p H}
$$

In Figure 6, the relationship of the $\mathrm{V}_{\mathrm{T}}$ and $\mathrm{pH}$ values in the range of 2 to 12 is revealed. From this graph, at a constant current of $\mathrm{I}_{\mathrm{DS}}=300 \mu \mathrm{A}$, the sensitivity was found to be approximately $66 \mathrm{mV} / \mathrm{pH}$ with a linearity of $99.3 \%$.

Three samples were measured using the same process and circumstances; the results were 63.7, 66 , and $68.1 \mathrm{mV} / \mathrm{pH}$ with an average value of $65.9 \mathrm{mV} / \mathrm{pH}$ with a standard deviation of \pm 2 . It was previously reported that the theoretical predictions from the Nernstian law indicate an upper limit for the EGFET value at about $59 \mathrm{mV} / \mathrm{pH}$ [23]. However, several reports revealed super Nernstian values can be achieved. The highest values from the reported articles were $62.87 \mathrm{mV} / \mathrm{pH}$ for PdO [23], 61.44 and $62.0 \mathrm{mV} / \mathrm{pH}$ for $\mathrm{TiO}_{2}$ [22,41], and $71.4 \mathrm{mV} / \mathrm{pH}$ for Pd-PdO [42]. Moreover, it was reported that a mixture of vanadium with $5 \%$ tungsten oxide achieved a sensitivity value of $68 \mathrm{mV} / \mathrm{pH}$ [43].

According to Zehfroosh et al. [21] and Yao et al. [22], the porous nature of the membrane surface will enhance the effective adsorption surface, which will result in the enhancement of the $\mathrm{pH}$ sensitivity of the sensor due to the increase of the charge accumulation, as more charges are accumulated, the current rises. 


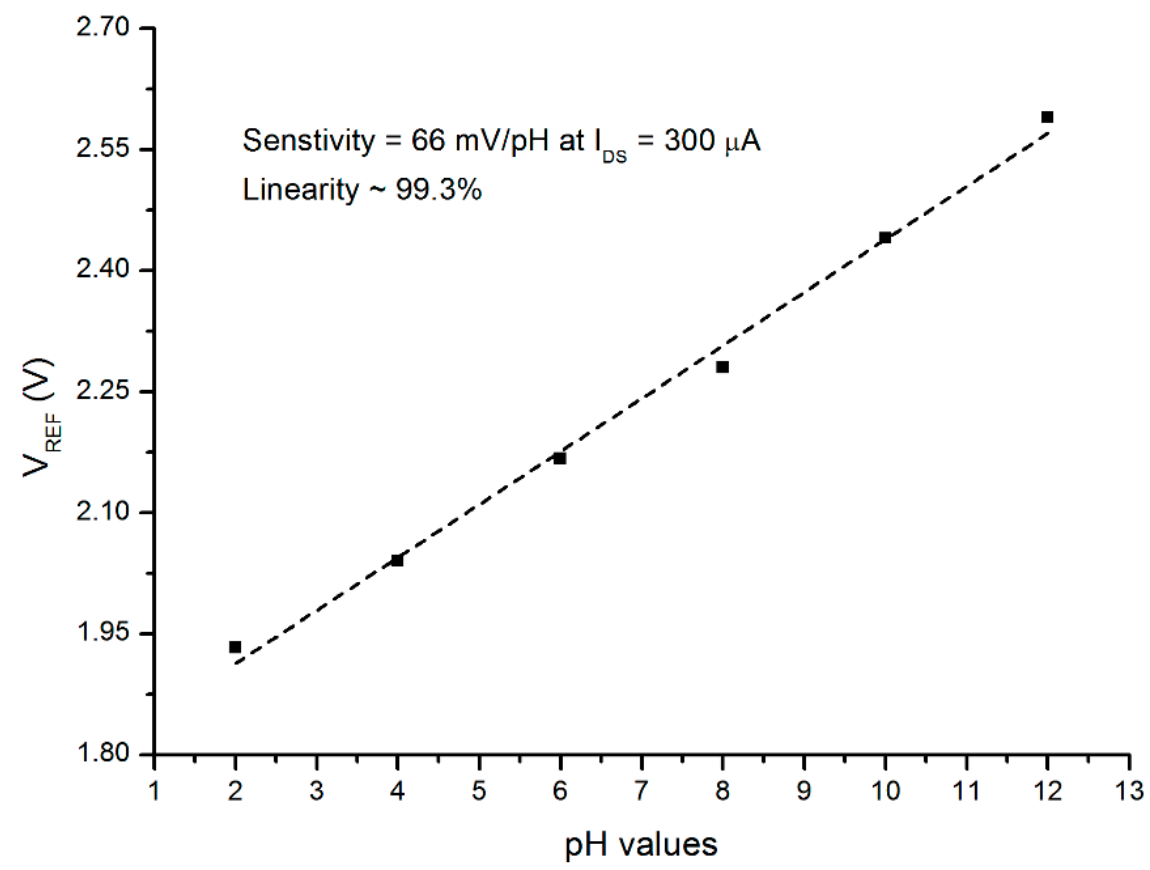

Figure 6. Sensitivity and linearity of prepared PSi EGFET vs. different $\mathrm{pH}$ buffer solutions $(\mathrm{pH}=2$ to 12). Black dots are measured data, and dashed line shows linear fit. $\mathrm{I}_{\mathrm{DS}}$ was kept constant at $300 \mu \mathrm{A}$.

For this, Zehfroosh et al. suggested a factor be added to Equation (5). The factor is related to the concentration of the hydrogen ions and the porosity of the membrane. In the view of the results obtained in this study, we believe that the main reaction is occurred between the ions $\left(\mathrm{H}^{+}\right.$and $\left.\mathrm{OH}^{-}\right)$ and the available sites on the surface of the PSi. Furthermore, the porosity of the prepared PSi and the accumulation of the charge play significant roles in the enhancement of the $\mathrm{pH}$ voltage sensitivity as more sites will be available for the ions to react with. On another word, the higher surface-to-volume ratio with larger effective surface area of the PSi are probably the main reason of the enhancement of the $\mathrm{pH}$ voltage sensitivity [44].

According to the Nernst equation, the error is $0.2 \mathrm{mV} / \mathrm{pH}$ per degree $\left({ }^{\circ} \mathrm{K}\right)$ at sensitivity of $59 \mathrm{mV} / \mathrm{pH}$ at $293{ }^{\circ} \mathrm{K}[23,42]$. In this experiment, the temperature was controlled at $25^{\circ} \mathrm{C} \pm 1{ }^{\circ} \mathrm{C}$ $\left(297^{\circ} \mathrm{K}\right.$ to $\left.299^{\circ} \mathrm{K}\right)$. The error at $2^{\circ} \mathrm{K}$ will be $0.4 \mathrm{mV}$, which is within the experimental error, and the temperature effect on the sensor output is insignificant.

The $I_{D S}-V_{D S}$ curves (also known as the saturated region) are depicted in Figure 7 (the $V_{\text {REF }}$ was kept constant at $3 \mathrm{~V}$ ). Here, the $\mathrm{I}_{\mathrm{DS}}$ values were shifted downward as the $\mathrm{pH}$ values increased. This is due to the decrease in the $\mathrm{H}^{+}$ion concentrations and the increase in the $\mathrm{OH}^{-}$ions, as the buffer solution altered from acidic to basic. Saturation sensitivity and linearity can be derived from Figure 7 . The sensitivity of the sensor from the saturated region can be calculated as:

$$
\mathrm{pH} \text { current senstivity }=\frac{\Delta \sqrt{I_{D S}}}{\Delta p H}
$$

From Figure 8, the $\mathrm{pH}$ sensitivity was $0.76 \mu \mathrm{A}^{1 / 2} / \mathrm{pH}$ with a linearity of $99.4 \%$, and the values of $\mathrm{I}_{\mathrm{DS}}$ were chosen at a constant $\mathrm{V}_{\mathrm{DS}}=3 \mathrm{~V}$. Table 1 reveals the results of the $\mathrm{pH}$ current sensitivity published by several authors. 


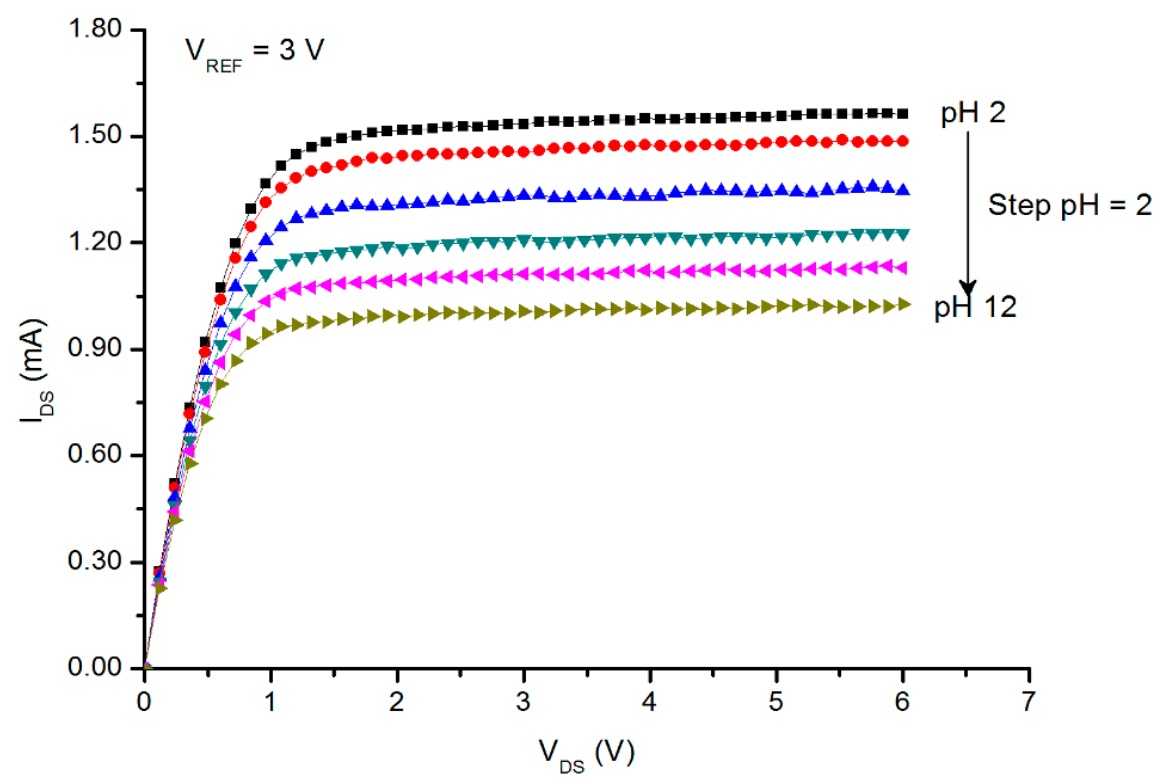

Figure 7. Plot of the $\mathrm{I}_{\mathrm{DS}}$ vs. the $\mathrm{V}_{\mathrm{DS}}$ of the prepared PSi pH sensor. $\mathrm{V}_{\mathrm{REF}}$ was kept constant at $3 \mathrm{~V}$. Buffer solutions were $\mathrm{pH}=2-12$.

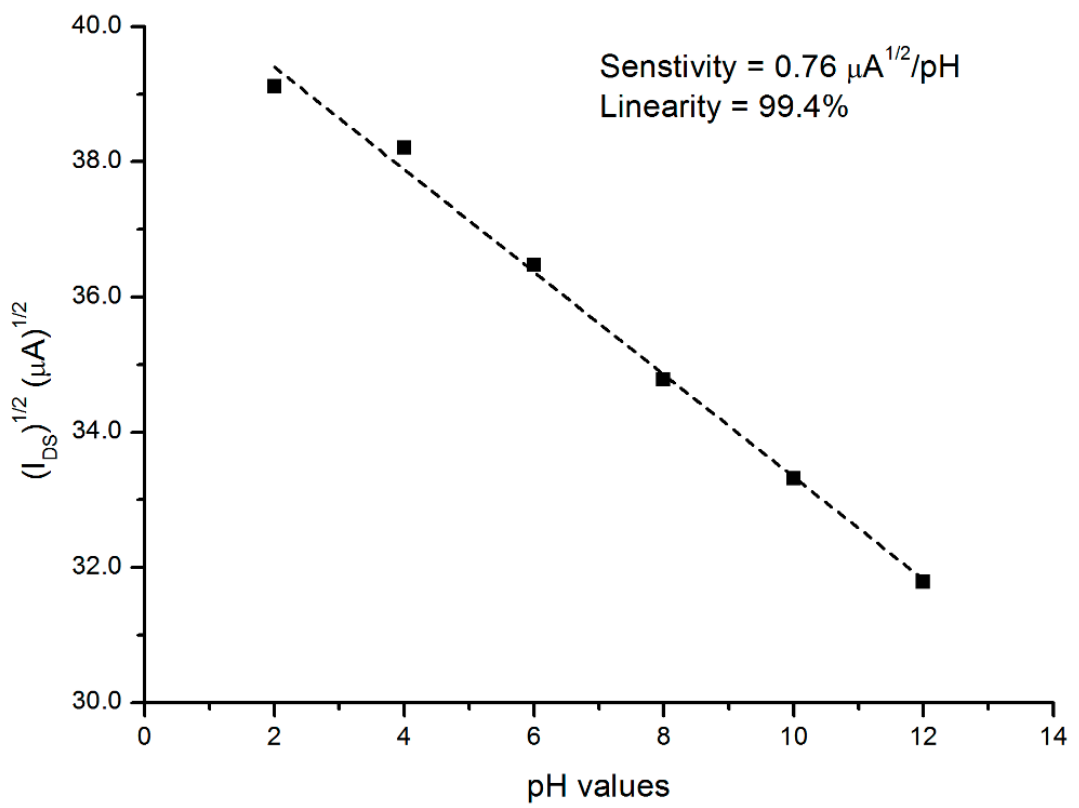

Figure 8. Plot of the $\sqrt{ } I_{D S}$ as a function of $\mathrm{pH}$ for the prepared PSi $\mathrm{pH}$ sensor. $V_{D S}$ and $V_{R E F}=3 \mathrm{~V}$. Black squares are measured data, and dashed line shows linear fit.

Table 1. The $\mathrm{pH}$ current sensitivity for various materials.

\begin{tabular}{cccc}
\hline Sensing Membrane & Platform & $\begin{array}{c}\text { Current Sensitivity } \\
\boldsymbol{\mu A}^{\mathbf{1 / 2} / \mathbf{p H}}\end{array}$ & Reference \\
\hline $\mathrm{PbO}$ thin film & EGFET & 1.08 & {$[23]$} \\
$\mathrm{V}_{2} \mathrm{O}_{5} / \mathrm{WO}_{3}$ thin film & EGFET & 1.36 & {$[43]$} \\
$\mathrm{ZnO} / \mathrm{Si}$ nanowire & EGFET & 0.73 & {$[45]$} \\
$\mathrm{ZnO}$ thin film & EGFET & 0.54 & {$[45]$} \\
$\mathrm{PSi}$ & EGFET & 0.76 & this study \\
\hline
\end{tabular}


Table 1 reveals the $\mathrm{pH}$ current sensitivity obtained by several research groups, based on different materials, compared with the results of this study.

Figure 9 depicts the hysteresis effect, and it was noticed that the hysteresis of the membrane was $8.2 \mathrm{mV}$ for the $\mathrm{pH} 7 \rightarrow \mathrm{pH} 4 \rightarrow \mathrm{pH} 7$ loop, and it was increased to $10.5 \mathrm{mV}$ for the $\mathrm{pH} 7 \rightarrow \mathrm{pH} 10 \rightarrow$ $\mathrm{pH} 7$ loop. The difference in the hysteresis value between the low $\mathrm{pH}$ loop and the high $\mathrm{pH}$ loop is due to the difference in the diffusion rates for $\mathrm{H}^{+}$and $\mathrm{OH}^{-}$ions in the surface-sites underneath the membrane surface (buried sites) [22].

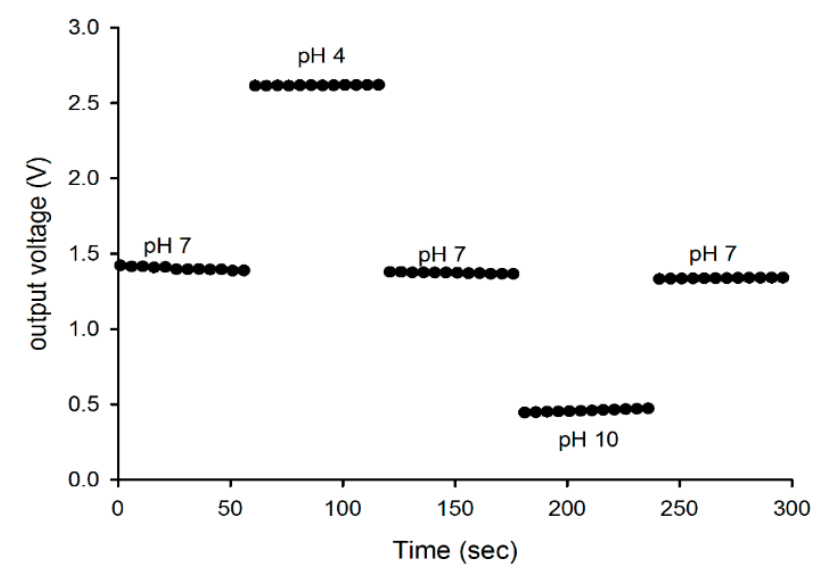

Figure 9. Hysteresis characteristics for prepared PSi membrane EGFET pH sensor.

The hysteresis is known to be related to the chemical interaction between the ions $\left(\mathrm{H}^{+}\right.$and $\mathrm{OH}^{-}$) in the electrolyte [46] and the slow reacting buried sites of the membrane surface and/or the surface defects of the membrane. Since the diffusion of $\mathrm{H}^{+}$ions into the buried sites of the sensing film is more rapid than that of the $\mathrm{OH}^{-}$ions, the hysteresis is more significant in an alkaline solution [22,23]. The results obtained in this study are slightly higher than that of the previous studies using metal-oxide-semiconductor membranes [23,39].

The performance of the prepared PSi in this study reveals a promising behavior in the field of pH measurements based on EGFET platform with a stable performance within the maximum and minimum pH range (2-12). According to Zhou et al. [47] and Fulati [44] ZnO nanostructure show a degradability at different $\mathrm{pH}$ values. Furthermore, several studies showed the disintegration of metal oxide semiconductors such as tin oxide [29] and tungsten trioxide [48] for $\mathrm{pH}$ sensing applications. On the other hand, $\mathrm{SiO}_{2}$ (on the surface of PSi) was reported to undergo a low dissolution rate compared with the above oxides [46,47]. This might be the reason for the stable performance. It is worth noting that $\mathrm{SiO}_{2}$ has been used frequently in ISFET for $\mathrm{pH}$ and other bio analytic detections [49]. The only drawback of using $\mathrm{SiO}_{2}$ as a membrane was the hysteresis effect with the alkaline aqueous solutions [46].

\section{Conclusions}

In summary, we report for the first time on the usage of PSi as a membrane for hydrogen ion sensing in a buffer solution with different $\mathrm{pH}$ values based on EGFET platform. The PSi membrane demonstrates a high value of sensitivity at $66 \mathrm{mV} / \mathrm{pH}$ in the $\mathrm{pH}$ value range between 2 and 12 . In view of the results obtained in this study, we believe that the porosity of the surface increases the accumulation of the charges that result in an increase of the sensitivity. The PSi membrane shows reasonably values of hysteresis between the $\mathrm{pH}$ values.

Acknowledgments: This work was supported by the Universiti Kebangsaan Malaysia (UKM) through short-term grant number DIP 2014-023 (UKM). The authors are also thankful to the Centre for Research and Instrumentation Management (CRIM) at UKM for providing the FE-SEM measurements. 
Author Contributions: N.H. Al-Hardan, M.A. Abdul Hamid, Naser M. Ahmed, and R. Shamsudin contributed equally to this work by conceiving and designing the experiments; N.H. Al-Hardan and Naser M. Ahmed performed the experiments. N.H. Al-Hardan and M.A. Abdul Hamid analyzed the data and drafted the manuscript. N.H. Al-Hardan and M.A. Abdul Hamid revised and proved that the draft manuscript. A. Jalar, N.K. Othman, Lim Kar Keng, W.S. Chiu, and Hamzah N. Al-Rawi gave technical support and conceptual advice.

Conflicts of Interest: The authors declare no conflict of interest.

\section{References}

1. Harraz, F.A. Porous silicon chemical sensors and biosensors: A review. Sens. Actuators B Chem. 2014, 202, 897-912. [CrossRef]

2. Palestino, G.; Legros, R.; Agarwal, V.; Pérez, E.; Gergely, C. Functionalization of nanostructured porous silicon microcavities for glucose oxidase detection. Sens. Actuators B Chem. 2008, 135, 27-34. [CrossRef]

3. Dhanekar, S.; Islam, S.S.; Islam, T.; Shukla, A.K. Organic vapour sensing by porous silicon: Influence of molecular kinetics in selectivity studies. Phys. E Low-Dimens. Syst. Nanostruct. 2010, 42, 1648-1652. [CrossRef]

4. Dhanekar, S.; Jain, S. Porous silicon biosensor: Current status. Biosens. Bioelectron. 2013, 41, 54-64. [CrossRef] [PubMed]

5. RoyChaudhuri, C. A review on porous silicon based electrochemical biosensors: Beyond surface area enhancement factor. Sens. Actuators B Chem. 2015, 210, 310-323. [CrossRef]

6. López-García, J.; Martín-Palma, R.J.; Manso, M.; Martínez-Duart, J.M. Porous silicon based structures for the electrical biosensing of glucose. Sens. Actuators B Chem. 2007, 126, 82-85. [CrossRef]

7. Koshida, N.; Koyama, H. Visible electroluminescence from porous silicon. Appl. Phys. Lett. 1992, 60, 347-349. [CrossRef]

8. Fauchet, P.M.; von Behren, J.; Hirschman, K.D.; Tsybeskov, L.; Duttagupta, S.P. Porous Silicon Physics and Device Applications: A Status Report. Phys. Status Solidi 1998, 165, 3-13. [CrossRef]

9. Canham, L.T.; Cox, T.I.; Loni, A.; Simons, A.J. Progress towards silicon optoelectronics using porous silicon technology. Appl. Surf. Sci. 1996, 102, 436-441. [CrossRef]

10. Ünal, B.; Parbukov, A.N.; Bayliss, S.C. Photovoltaic properties of a novel stain etched porous silicon and its application in photosensitive devices. Opt. Mater. 2001, 17, 79-82. [CrossRef]

11. Balagurov, L.A.; Bayliss, S.C.; Yarkin, D.G.; Andrushin, S.Y.; Kasatochkin, V.S.; Orlov, A.F.; Petrova, E.A. Low noise photosensitive device structures based on porous silicon. Solid-State Electron. 2003, 47, 65-69. [CrossRef]

12. Hadjersi, T.; Gabouze, N. Photodetectors based on porous silicon produced by Ag-assisted electroless etching. Opt. Mater. 2008, 30, 865-869. [CrossRef]

13. Balucani, M.; Bondarenko, V.; Klusko, A.; Ferrari, A. Recent progress in integrated waveguides based on oxidized porous silicon. Opt. Mater. 2005, 27, 776-780. [CrossRef]

14. Liyanage, C.N.; Blackwood, D.J. Functionalization of a porous silicon impedance sensor. Thin Solid Films 2014, 550, 677-682. [CrossRef]

15. Massera, E.; Nasti, I.; Quercia, L.; Rea, I.; Di Francia, G. Improvement of stability and recovery time in porous-silicon-based $\mathrm{NO}_{2}$ sensor. Sens. Actuators B Chem. 2004, 102, 195-197. [CrossRef]

16. Mahmoudi, B.; Gabouze, N.; Haddadi, M.; Mahmoudi, B.; Cheraga, H.; Beldjilali, K.; Dahmane, D. The effect of annealing on the sensing properties of porous silicon gas sensor: Use of screen-printed contacts. Sens. Actuators B Chem. 2007, 123, 680-684. [CrossRef]

17. Kanungo, J.; Saha, H.; Basu, S. Room temperature metal-insulator-semiconductor (MIS) hydrogen sensors based on chemically surface modified porous silicon. Sens. Actuators B Chem. 2009, 140, 65-72. [CrossRef]

18. Anglin, E.J.; Cheng, L.; Freeman, W.R.; Sailor, M.J. Porous silicon in drug delivery devices and materials. Adv. Drug Deliv. Rev. 2008, 60, 1266-1277. [CrossRef] [PubMed]

19. Chen, C.-C.; Chen, H.-I.; Liu, H.-Y.; Chou, P.-C.; Liou, J.-K.; Liu, W.-C. On a GaN-based ion sensitive field-effect transistor (ISFET) with a hydrogen peroxide surface treatment. Sens. Actuators B Chem. 2015, 209, 658-663. [CrossRef]

20. Xu, F.; Yan, G.; Wang, Z.; Jiang, P. Continuous accurate $\mathrm{pH}$ measurements of human GI tract using a digital pH-ISFET sensor inside a wireless capsule. Measurement 2015, 64, 49-56. [CrossRef] 
21. Zehfroosh, N.; Shahmohammadi, M.; Mohajerzadeh, S. High-Sensitivity Ion-Selective Field-Effect Transistors Using Nanoporous Silicon. IEEE Electron Device Lett. 2010, 31, 1056-1058. [CrossRef]

22. Yao, P.-C.; Chiang, J.-L.; Lee, M.-C. Application of sol-gel $\mathrm{TiO}_{2}$ film for an extended-gate H+ ion-sensitive field-effect transistor. Solid State Sci. 2014, 28, 47-54. [CrossRef]

23. Das, A.; Ko, D.H.; Chen, C.-H.; Chang, L.-B.; Lai, C.-S.; Chu, F.-C.; Chow, L.; Lin, R.-M. Highly sensitive palladium oxide thin film extended gate FETs as pH sensor. Sens. Actuators B Chem. 2014, 205, 199-205. [CrossRef]

24. Batista, P.D.; Mulato, M. ZnO extended-gate field-effect transistors as pH sensors. Appl. Phys. Lett. 2005, 87, 143508-143511. [CrossRef]

25. Chiu, Y.-S.; Tseng, C.-Y.; Lee, C.-T. Nanostructured EGFET pH Sensors With Surface-Passivated ZnO Thin-Film and Nanorod Array. IEEE Sens. J. 2012, 12, 930-934. [CrossRef]

26. Liao, Y.-H.; Chou, J.-C. Preparation and characterization of the titanium dioxide thin films used for $\mathrm{pH}$ electrode and procaine drug sensor by sol-gel method. Mater. Chem. Phys. 2009, 114, 542-548. [CrossRef]

27. Sardarinejad, A.; Maurya, D.; Alameh, K. The pH Sensing Properties of RF Sputtered $\mathrm{RuO}_{2} \mathrm{Thin}-\mathrm{Film}$ Prepared Using Different Ar/O $\mathrm{O}_{2}$ Flow Ratio. Materials 2015, 8, 3352-3363. [CrossRef]

28. Batista, P.; Mulato, M. Polycrystalline fluorine-doped tin oxide as sensoring thin film in EGFET pH sensor. J. Mater. Sci. 2010, 45, 5478-5481. [CrossRef]

29. Chou, J.-C.; Kwan, P.K.; Chen, Z.-J. $\mathrm{SnO}_{2}$ Separative Structure Extended Gate $\mathrm{H}^{+}$Ion Sensitive Field Effect Transistor by the Sol-Gel Technology and the Readout Circuit Developed by Source Follower. Jpn. J. Appl. Phys. 2003, 42, 6790. [CrossRef]

30. Reddy, R.R.K.; Chadha, A.; Bhattacharya, E. Porous silicon based potentiometric triglyceride biosensor. Biosens. Bioelectron. 2001, 16, 313-317. [CrossRef]

31. Reddy, R.R.K.; Basu, I.; Bhattacharya, E.; Chadha, A. Estimation of triglycerides by a porous silicon based potentiometric biosensor. Curr. Appl. Phys. 2003, 3, 155-161. [CrossRef]

32. Schöning, M.; Simonis, A.; Ruge, C.; Ecken, H.; Müller-Veggian, M.; Lüth, H. A (Bio-) Chemical Field-Effect Sensor with Macroporous $\mathrm{Si}$ as Substrate Material and a $\mathrm{SiO}_{2} / \mathrm{LPCVD}-\mathrm{Si}_{3} \mathrm{~N}_{4}$ Double Layer as $\mathrm{pH}$ Transducer. Sensors 2002, 2, 11-22. [CrossRef]

33. Yates, D.E.; Levine, S.; Healy, T.W. Site-binding model of the electrical double layer at the oxide/water interface. J. Chem. Soc. Faraday Trans. 1 Phys. Chem. Condens. Phases 1974, 70, 1807-1818. [CrossRef]

34. Tae-Eon, B.; Hyun-June, J.; Se-Won, L.; Won-Ju, C. Enhanced Sensing Properties by Dual-Gate Ion-Sensitive Field-Effect Transistor Using the Solution-Processed $\mathrm{Al}_{2} \mathrm{O}_{3}$ Sensing Membranes. Jpn. J. Appl. Phys. 2013, 52, 06 GK03.

35. Oldham, K.B. A Gouy-Chapman-Stern model of the double layer at a (metal)/(ionic liquid) interface. J. Electroanal. Chem. 2008, 613, 131-138. [CrossRef]

36. Pan, T.-M.; Huang, M.-D.; Lin, C.-W.; Wu, M.-H. Development of high-k $\mathrm{HoTiO}_{3}$ sensing membrane for $\mathrm{pH}$ detection and glucose biosensing. Sens. Actuators B Chem. 2010, 144, 139-145. [CrossRef]

37. Parizi, K.B.; Yeh, A.J.; Poon, A.S.Y.; Wong, H.S.P. Exceeding Nernst limit ( $59 \mathrm{mV} / \mathrm{pH})$ : CMOS-based pH sensor for autonomous applications, Electron Devices Meeting (IEDM). In Proceedings of the 2012 IEEE International, San Francisco, CA, USA, 10-13 December 2012; pp. 24.7.1-24.7.4.

38. Spijkman, M.; Smits, E.C.P.; Cillessen, J.F.M.; Biscarini, F.; Blom, P.W.M.; de Leeuw, D.M. Beyond the Nernst-limit with dual-gate $\mathrm{ZnO}$ ion-sensitive field-effect transistors. Appl. Phys. Lett. 2011, 98, 043502. [CrossRef]

39. Mahmoud, N.; Hassan, Z.; Abd, H.R. Design of Metal-Semiconductor-Metal Photodetector: Porous Silicon Photodetector; Lap Lambert Academic Publishing GmbH KG: Saarbrücken, Germany, 2012.

40. Yin, L.-T.; Chou, J.-C.; Chung, W.-Y.; Sun, T.-P.; Hsiung, S.-K. Separate structure extended gate $\mathrm{H}^{+}$ion sensitive field effect transistor on a glass substrate. Sens. Actuators B Chem. 2000, 71, 106-111. [CrossRef]

41. Huang, Y.-C.; Tai, F.-S.; Wang, S.-J. Preparation of $\mathrm{TiO}_{2}$ nanowire arrays through hydrothermal growth method and their $\mathrm{pH}$ sensing characteristics. Jpn. J. Appl. Phys. 2014, 53, 06JG02. [CrossRef]

42. Liu, C.-C.; Bocchicchio, B.C.; Overmyer, P.A.; Neuman, M.R. A Palladium-Palladium Oxide Miniature pH Electrode. Science 1980, 207, 188-189. [CrossRef] [PubMed]

43. Guidelli, E.J.; Guerra, E.M.; Mulato, M. $\mathrm{V}_{2} \mathrm{O}_{5} / \mathrm{WO}_{3}$ Mixed Oxide Films as pH-EGFET Sensor: Sequential Re-Usage and Fabrication Volume Analysis. ECS J. Solid State Sci. Technol. 2012, 1, N39-N44. [CrossRef] 
44. Fulati, A.; Usman Ali, S.M.; Riaz, M.; Amin, G.; Nur, O.; Willander, M. Miniaturized pH Sensors Based on Zinc Oxide Nanotubes/Nanorods. Sensors 2009, 9, 8911-8923. [CrossRef] [PubMed]

45. Li, H.-H.; Yang, C.-E.; Kei, C.-C.; Su, C.-Y.; Dai, W.-S.; Tseng, J.-K.; Yang, P.-Y.; Chou, J.-C.; Cheng, H.-C. Coaxial-structured $\mathrm{ZnO} /$ silicon nanowires extended-gate field-effect transistor as $\mathrm{pH}$ sensor. Thin Solid Films 2013, 529, 173-176. [CrossRef]

46. Luc, B.; Bergveld, P. The Role of Buried $\mathrm{OH}^{-}$Sites in the Response Mechanism of Inorganic-Gate $\mathrm{pH}-$ Sensitive ISFETs. Sens. Actuators 1984, 6, 65-78.

47. Zhou, J.; Xu, N.; Wang, Z.L. Dissolving Behavior and Stability of ZnO Wires in Biofluids: A Study on Biodegradability and Biocompatibility of ZnO Nanostructures. Adv. Mater. 2006, 18, 2432-2435. [CrossRef]

48. Chou, J.C.; Chiang, J.L. Study on the amorphous tungsten trioxide ion-sensitive field effect transistor. Sens. Actuators B Chem. 2000, 66, 106-108. [CrossRef]

49. Luo, X.; Xu, J.; Zhao, W.; Chen, H. Glucose biosensor based on ENFET doped with $\mathrm{SiO}_{2}$ nanoparticles. Sens. Actuators B Chem. 2004, 97, 249-255. [CrossRef]

(c) 2016 by the authors; licensee MDPI, Basel, Switzerland. This article is an open access article distributed under the terms and conditions of the Creative Commons Attribution (CC-BY) license (http://creativecommons.org/licenses/by/4.0/). 